\title{
FIEDLER'S MYOCARDITIS
}

\author{
BY \\ J. A. PARRISH* \\ From Chase Farm Hospital, Enfield, Middlesex
}

\begin{abstract}
Although Fiedler in 1900 described patients with isolated myocarditis and the hearts from these patients were described by Schmorl (quoted by Saphir, 1941, 1942) as containing numerous giant cells, the term Fiedler's myocarditis has for many years been used for a variety of types of myocarditis. In view of the lack of evidence in the majority of cases to suggest specific ætiology they have been classified according to the pathological findings by Boikan (1931), Saphir (1941, 1942), and Tesluk (1956).

It has been suggested that diagnosis is uncommon in life (Saphir, 1941, 1942; Lieberman, 1957), though Saphir did not quote any figure for this in his 240 cases of myocarditis diagnosed at necropsy. The present case is of interest because a presumptive diagnosis of myocarditis of the Fiedler type was made before death and also because of the histological appearances of the giant cells in the heart.
\end{abstract}

\section{Case Report}

A woman of 35, a housewife with five children, complained that for four months she had had increasing lassitude and inability to manage her housework. There had been anorexia for a month. Two days before admission she developed sudden severe pain at the lower end of the sternum while lying in bed. This pain only occurred on deep breathing and it persisted through the night. The patient was seen by her medical attendant in the morning and given paracetamol and amytal and the pain had completely gone by mid-day. Retrosternal pain recurred in the evening after her meal but was attributed to indigestion and relieved by milk. This pain was associated with shortness of breath and was worse when she was lying flat. She became progressively weaker and noted palpitations over the next two days but had no cough or ankle œdema.

Past History. There had been no rheumatic fever, no syphilis, and no recent family illness.

On admission, the patient was very weak and anxious but lay still, pale but with malar flush. Temperature was $98 \cdot 6^{\circ} \mathrm{F}$. $\left(37^{\circ} \mathrm{C}\right.$.). There was no cyanosis, jaundice, or lymphadenopathy. No abnormality was found in the nervous system or lungs and there was no œdema. The liver was enlarged three finger breadths below the costal margin and was tender. The pulse was regular at 140 a minute, but poor in volume. The venous pressure was raised. Blood pressure $80 / 60 \mathrm{~mm}$. $\mathrm{Hg}$. The apex beat was not displaced. The heart sounds were quiet and gallop rhythm was present; no murmurs were heard.

Investigations. $\mathrm{Hb} 83$ per cent or $12.2 \mathrm{~g}$.; erythrocyte sedimentation rate, $6 \mathrm{~mm}$. in 1 hour (Westergren). Total white blood cells 12,000; neutrophil polymorphs, 73 per cent, lymphocytes 23 per cent, monocytes 4 per cent. Blood urea: $42 \mathrm{mg}$. $/ 100 \mathrm{ml}$. Serum glutamic oxalic transaminase, $130 \mathrm{SF}$ units (normal $4-40$ ). Serum lactic dehydrogenase, 1320 units $/ \mathrm{ml}$. (normal 150-400). Serum bilirubin, $0.7 \mathrm{mg} . / 100 \mathrm{ml}$. Alkaline phosphatase, $5.6 \mathrm{~K}$.A. units. Total serum proteins, $6.5 \mathrm{~g} . / 100 \mathrm{ml}$; albumin $4.6 \mathrm{~g} . / 100 \mathrm{ml}$., globulin $1.9 \mathrm{~g} . / 100 \mathrm{ml}$. Chest radiograph showed the heart to be slightly enlarged and this enlargement appeared to be confined to the ventricles. Moderate vascular congestion was present at the hila. The electrocardiogram showed low voltage in all leads and tachycardia (Fig. 1).

A diagnosis of myocarditis was made on admission, and following investigations this was considered to be an isolated myocarditis probably of the Fiedler type.

The patient's clinical condition had deteriorated rapidly in the two days before admission and continued to do so afterwards. It was felt that she required treatment for her heart failure and she was given digoxin cautiously by mouth. Over the next 24 hours there was no improvement, her general condition became

* Present address: St. Bartholomew's Hospital, London. 

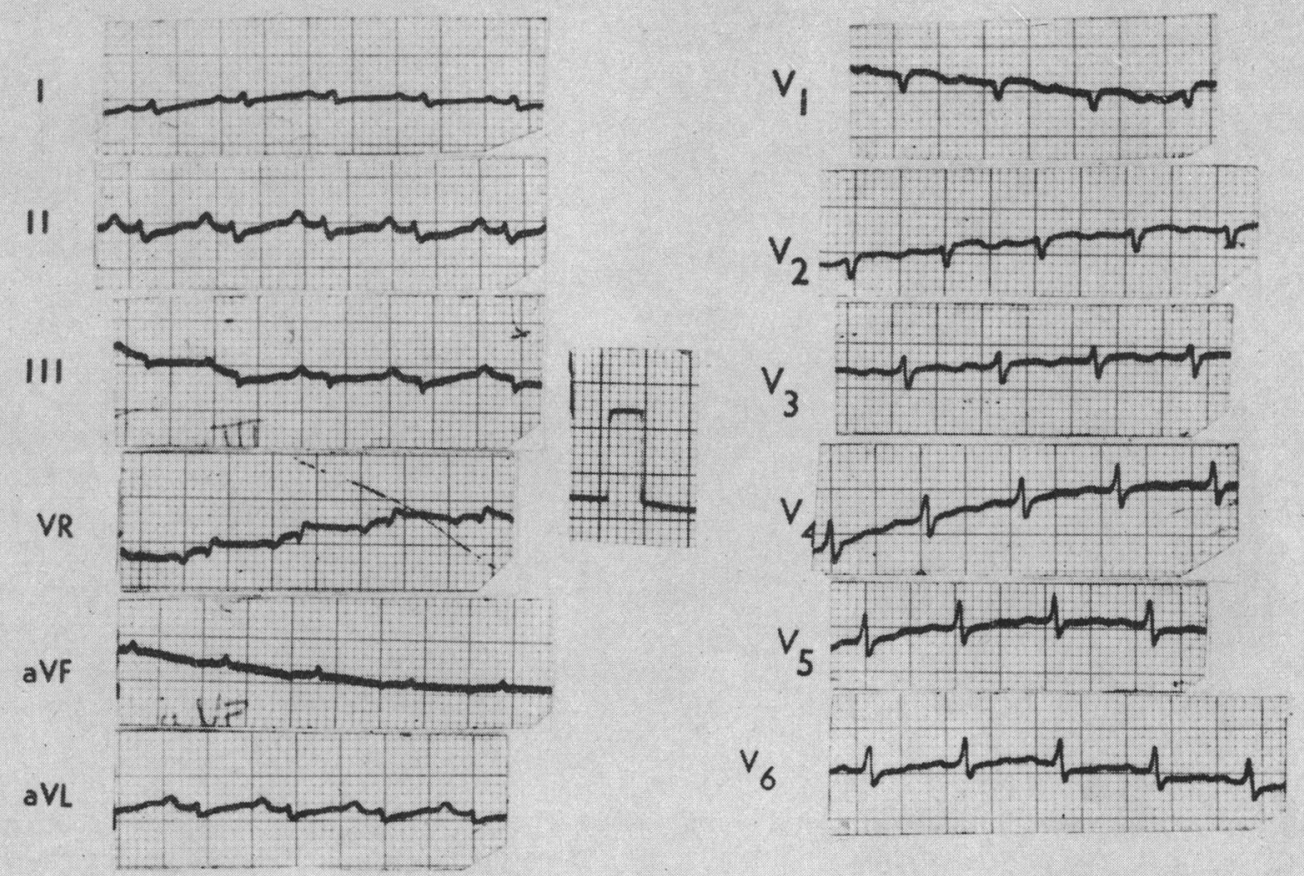

Fig. 1.-Electrocardiogram showing tachycardia and low voltage tracing.

weaker and the systolic pressure fell to $55 \mathrm{~mm}$. Hg. She then developed peripheral vascular failure and a slow intravenous drip with l-noradrenaline and hydrocortisone was begun. Mephine was added later but in spite of these measures she became progressively weaker and died 84 hours after admission. On admission her temperature had been $98 \cdot 6^{\circ} \mathrm{F}$. $\left(37^{\circ} \mathrm{C}\right.$.) but subsequently it remained well below normal at $96^{\circ}-97^{\circ} \mathrm{F}$. $\left(35 \cdot 6-36 \cdot 1{ }^{\circ} \mathrm{C}.\right)$.

Necropsy (Dr. Prendiville). There were numerous petechiæ in the mediastinal tissues and over the parietal pleura on the heart wall, into the parietal and beneath the visceral pericardium. There were a few millilitres only of normal-looking fluid in the pericardial sac. The heart weighed $235 \mathrm{~g}$. The entire myocardium showed pathological changes. The greater part of it was very pale, soft, and necrotic-looking. The remainder of it was mottled red and pale. There were some small vegetations attached to the endocardium in the left ventricle. The valves appeared quite normal. The papillary muscles however appeared to be involved in the lesion. Coronary arteries were normal. There were about two pints of clear transudate in each pleural sac. There was a small amount of bloody mucoid material in the trachea which itself appeared normal. The main bronchi were normal. The smaller bronchi in the lower lobes of both lungs were plugged with thick pus. The lung parenchyma on both sides showed no abnormality. There was no pulmonary œdema. The liver was enlarged and showed an early nutmeg appearance. The spleen was normal in size but very soft. There were petechiæ of and ecchymoses into the peri-renal fat on both sides. The skeletal muscles appeared normal. No other abnormalities were found.

Histology. Numerous sections cut through all chambers of the heart showed similar appearances. The pericardium and endocardium were normal, the myocardium alone being damaged. Although some groups of heart muscle fibres remained, there were extensive areas of degenerating muscle and other areas with no evidence of muscle fibres. In the areas of degenerating muscle there were numerous myogenic giant cells (Fig. 2 and 3), infiltration with mononuclear cells which were principally lymphocytes together 


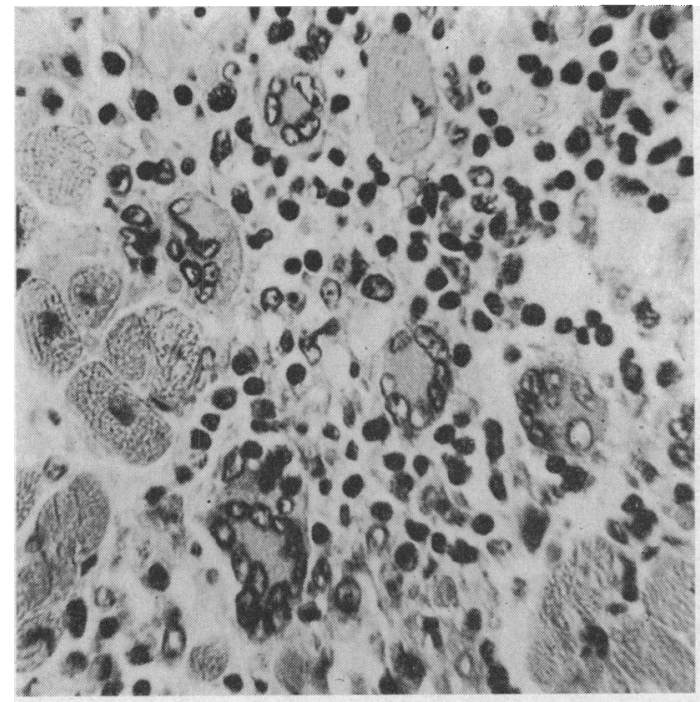

FIG. 2.-Muscle fibres cut transversely to show "circular" myogenic giant cells. $(\times 350$.)

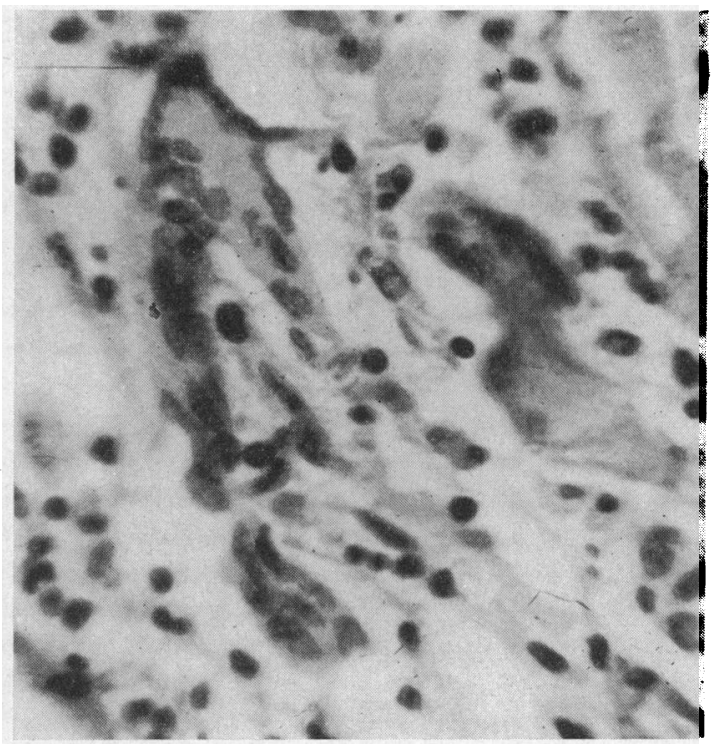

FIG. 3.-Section shows fragmentation of muscle fibres and collection of nuclei in fragments forming myogenic giant cell. $(\times 450$.

with many eosinophils, plasma cells, and round cells. The almost complete absence of neutrophil polymorphonuclear cells was remarkable. Although the endocardium was not thickened the papillary muscles were involved in the muscle degeneration. In some areas there were numerous small well-filled capillaries and early fibroblast proliferation suggesting that there was some repair continuing at the same time as the active degeneration.

\section{Discussion}

In 1956 Dilling could find 13 previously reported examples of myocarditis with giant cells and since then at least 6 others have been described, 3 in men (Tesluk, 1956; Collyns, 1959; Rab, Choudhury, and Choudhury, 1963), and 3 in women (Naddachina, 1961; Long, 1961; D’Agostino, Avella, and Maddaluno, 1962) ranging from 19 to 54 years in age.

This patient's clinical picture together with the serum enzymes and electrocardiogram suggested a diagnosis of myocarditis and in the total absence of any obvious ætiological agency or cardiac enlargement, a presumptive diagnosis of Fiedler's myocarditis was made. Over 50 sections were taken from the various chambers of the heart, and it was estimated that approximately 80 per cent of the heart muscle had been destroyed. It is clear that neither cardiac stimulants nor steroids as suggested by Gubbay (1961) could have helped at this stage.

The histological findings that seem to make this a specific group amongst the myocarditides are first the presence of giant cells and secondly the large numbers of lymphocytes, eosinophils, and plasma cells with an almost total lack of neutrophil polymorphs.

Although the origin of the giant cells has given rise to conjecture (Saphir, 1941, 1942; Tesluk, 1956; Collyns, 1959; Long, 1961), it seems clear that in this case the giant cells were from degenerating muscle. Where the heart muscle fibres were cut transversely, tangentially, or longitudinally so the giant cells were cut in the same fashion. The appearances were similar to those demonstrated by Denny-Brown (1960) and Adams, Denny-Brown, and Pearson (1962) as a result of trauma in skeletal muscle. The accumulation or gathering of nuclei in the fragmented muscle fibres may be analogous to the changes described by Professor Ashton (1963) in the capillaries of the retina where nuclei appear to graduate to one part of a capillary from a length of ischæmic vessel. 
The ætiology remains uncertain but the lack of polymorphs argues against a bacterial infection in spite of the peripheral blood picture. Neither is there much evidence to incriminate a virus, and considering the prevalence of most viruses and the relative rarity of this condition, this seems unlikely. It is possible that what might be a recognizable pathological pattern in another site is modified by the continuous prolonged heart action and it would simplify the classification of these disorders if it could be assumed that some cases of acute isolated myocarditis without myogenic giant cells might have developed muscle degeneration if the process had been less acute. The picture however is not incompatible with an autosensitization reaction to heart muscle proteins.

The question of earlier diagnosis is made extremely difficult because symptoms of lethargy and tiredness are not uncommon in hard-worked mothers with many children. However, if a diagnosis were to be suggested both clinically and by a cardiogram, one could expect the serum enzyme levels to be of further help in diagnosis, and this point is well illustrated by the findings in this case.

\section{Summary}

A case of Fiedler's giant cell myocarditis is described occurring in a young woman, in whom diagnosis was made before death and whose histological features strongly suggested that the giant cells were myogenic in origin. The ineffectiveness of treatment in the later stages is mentioned.

I should like to thank Dr. C. Allan Birch for permission to publish this case; Dr. Prendiville for his advice in the preparation of this report and Mr. D. Oakman and the department of photography at Chase Farm Hospital for the sections and photographs.

\section{References}

Adams, R. D., Denny-Brown, D., and Pearson, C. M. (1962). Diseases of Muscle. A Study in Pathology, 2nd ed. Harper, New York.

Ashton, N. (1963). Joint Meeting of British Diabetic and Irish Opthalmological Societies. Dublin.

Boikan, W. S. (1931). Myocarditis perniciosa. Virchows Arch. path. Anat., 282, 46.

Collyns, J. A. H. (1959) Isolated granulomatous myocarditis. Amer. Heart J., 58, 630.

D’Agostino, S., Avella, A., and Maddaluno, R. (1962). Considerazioni su un caso di miocardite interstiziale acuta tipo Fiedler e di miosite granulomatose associate a tumore timico Rass. Clin. Ter., 61, 118.

Denny-Brown, D. (1960). Experimental studies pertaining to hypertrophy, regeneration and degeneration. In Neuromuscular Disorders. Res. Publ. Ass. nerv. ment. Dis., 38, 147.

Dilling, N. V. (1956). Giant-cell myocarditis. J. Path. Bact., 71, 295.

Fiedler, A. (1900). Uber akute interstitielle Myokarditis. Zbl. inn. Med., 21, 212.

Gubbay, E. R. (1961). Idiopathic giant cell myocarditis. Canad. med. Ass. J., 85, 349.

Lieberman, A. (1957). The allergic basis of Fiedler's myocarditis; with discussion of two case histories. Geriatrics, $12,485$.

Long, W. H. (1961). Granulomatous (Fiedler's) myocarditis with extracardiac involvement. A case report with sudden death. J. Amer. med. Ass., 177, 184.

Naddachina, T. A. (1961). A case of giant cell idiopathic myocarditis. Arkh. Pat., 23, no. 5, p. 68.

Rab, S. M., Choudhury, G. M., and Choudhury, A. R. (1963). Giant-cell myocarditis. Lancet, 2, 172.

Saphir, O. (1941). Myocarditis. A general review, with an analysis of 240 cases. Arch. Path., 32, 1000.

(1942). Myocarditis. A general review, with an analysis of 240 cases. Arch. Path., 33, 88.

Tesluk, H. (1956). Giant cell versus granulomatous myocarditis. Amer. J. clin. Path., 26, 1326. 